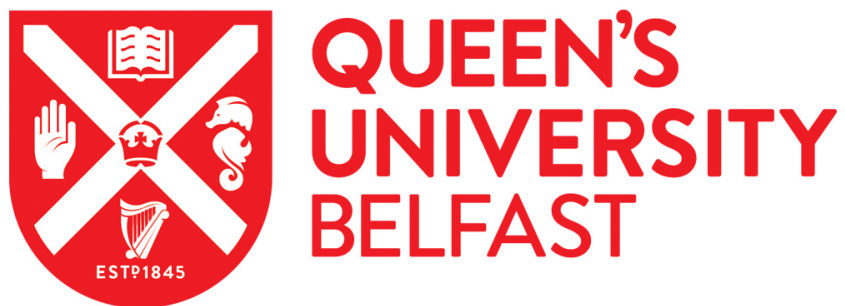

\section{A fast magnetic bead-based colorimetric immunoassay for the detection of tetrodotoxins in shellfish}

Campàs, M., Reverté, J., Rambla-Alegre, M., Campbell, K., Gerssen, A., \& Diogène, J. (2020). A fast magnetic bead-based colorimetric immunoassay for the detection of tetrodotoxins in shellfish. Food \& Chemical Toxicology, 140, 111315. https://doi.org/10.1016/j.fct.2020.111315

Published in:

Food \& Chemical Toxicology

Document Version:

Peer reviewed version

Queen's University Belfast - Research Portal:

Link to publication record in Queen's University Belfast Research Portal

\section{Publisher rights}

Copyright 2020 Elsevier Ltd.

This manuscript is distributed under a Creative Commons Attribution-NonCommercial-NoDerivs License

(https://creativecommons.org/licenses/by-nc-nd/4.0/), which permits distribution and reproduction for non-commercial purposes, provided the author and source are cited.

\section{General rights}

Copyright for the publications made accessible via the Queen's University Belfast Research Portal is retained by the author(s) and / or other copyright owners and it is a condition of accessing these publications that users recognise and abide by the legal requirements associated with these rights.

Take down policy

The Research Portal is Queen's institutional repository that provides access to Queen's research output. Every effort has been made to ensure that content in the Research Portal does not infringe any person's rights, or applicable UK laws. If you discover content in the Research Portal that you believe breaches copyright or violates any law, please contact openaccess@qub.ac.uk. 


\section{A fast magnetic bead-based colorimetric immunoassay for the detection of tetrodotoxins in shellfish}

Mònica Campàs $\mathrm{a}^{\mathrm{a}^{*}}$, Jaume Revertéa, Maria Rambla-Alegrea, Katrina Campbell ${ }^{\mathrm{b}}$, Arjen Gerssen ${ }^{\mathrm{c}}$, Jorge Diogène ${ }^{a}$

alRTA, Ctra. Poble Nou, km 5.5, 43540 Sant Carles de la Ràpita, Tarragona, Spain

'Institute for Global Food Security, School of Biological Sciences, Queen's University Belfast, David Keir Building, Stranmillis Road, Belfast, BT9 5AG, Northern Ireland, United Kingdom ${ }^{c}$ Wageningen Food Safety Research - Wageningen University and Research, 6700 AE, Wageningen, The Netherlands

*e-mail: monica.campas@irta.cat

\section{Abstract}

Tetrodotoxin (TTX) is a potent neurotoxin responsible for many food poisoning incidents and some fatalities. Although mainly associated with the consumption of pufferfish, in recent years, TTX has been found in shellfish, particularly in Europe. In this work, a magnetic bead (MB)-based colorimetric immunoassay was applied to the detection of TTX in Pacific oysters (Crassostrea gigas), razor clams (Solen marginatus) and mussels (Mytilus galloprovincialis). Effective LODs (eLODs) for TTX of $1 \mu \mathrm{g} / \mathrm{kg}$ in oysters and razor clams and $3.3 \mu \mathrm{g} / \mathrm{kg}$ in mussels, significantly below the EFSA guidance threshold $(44 \mu \mathrm{g} / \mathrm{kg})$, were obtained. The strategy was applied to the analysis of naturally-contaminated Pacific oysters (Crassostrea gigas) and mussels (Mytilus edulis) from the Netherlands, and TTX was detected in all samples. The approach, which takes less than 1.5 hours, proved to be useful as a rapid and simple method to detect TTX, support shellfish safety and protect consumers.

Keywords: Tetrodotoxin, immunoassay, magnetic bead (MB), shellfish, seafood poisoning. 


\section{INTRODUCTION}

Tetrodotoxin (TTX), a potent neurotoxin that blocks voltage-gated sodium ( $\mathrm{Na}^{+}$) channels in nerve and muscle tissue, is responsible for many food poisoning incidents and some fatalities, mainly associated with the consumption of some pufferfish species (Bane et al., 2014). TTX has also been found in other organisms, such as blue-ring octopus, ribbon worms, starfish, xanthid crabs, frogs and newts (Noguchi et al., 2006; Bane et al., 2014). TTX has been observed to be produced by bacteria of several genera such as Vibrio, Pseudomonas, Aeromonas, Alteromonas, Bacillus and Micrococcus (Magarlamov et al., 2017). However, since TTX-producing bacteria have not always been found in the host organisms, accumulation of TTX and TTX analogues along the food webs is also a hypothesis to explain their presence in some animals.

Recently, TTX has also been found in shellfish. In Europe, the concern arose in 2007, when contaminated trumpet shells (Charonia lampas lampas) from Portugal were identified as responsible for an intoxication case in Spain (Rodriguez et al., 2008). Since then, TTX has been found in shellfish from several European countries, including the United Kingdom (Turner et al., 2015), Greece (Vlamis et al., 2015), the Netherlands (Gerssen et al., 2018), Spain (Leão et al., 2018), and Italy (Dell'Aversano et al., 2019), although usually at very low concentrations. The European Food Safety Authority (EFSA) has concluded that concentrations below $44 \mu \mathrm{g}$ of TTX equiv./kg shellfish meat, based on a large portion size of $400 \mathrm{~g}$, do not result in adverse effects in humans (EFSA, 2017). Therefore, analytical methods under development aim at reaching this threshold, which is much lower than the value of $2 \mathrm{mg}$ TTX equiv./kg edible portion that is used in Japan as the acceptance criterion to consider puffer fish safe for consumption (Mahmud et al., 1999).

Bioanalytical methods, such as immunoassays, can be used to detect the presence of TTX and can contribute to protect consumer health from this toxin. The presence of TTX and its analogues in samples can be detected in a rapid, simple, specific, sensitive and reliable way using 
immunoassays. In our previous work, an immunoassay using microtiter plates for TTXs was developed and applied to the analysis of shellfish (Reverté et al., 2018), but that immunoassay experienced strong shellfish matrix effects (antibody binding percentage values lower than $80 \%$ in the absence of TTX). These undesirable effects were solved with a solid-phase extraction (SPE) clean up followed by solvent evaporation prior to the immunoassay. However, these steps substantially decreased the TTX recovery. In this work, the immunoassay was performed on magnetic beads (MBs) in suspension instead of microtiter plates, a strategy exploited previously by our group for the development of an electrochemical immunosensor for TTXs in juvenile puffer fish (Leonardo et al., 2019). The system is based on the immobilisation of TTX on MBs followed by a competition for an anti-TTX monoclonal antibody (mAb) and the subsequent incubation with a secondary antibody (IgG-HRP) for colour development (Fig. 1). This approach already decreased the matrix effects observed in the analysis of TTXs in a puffer fish liver sample. Therefore, in this work, the applicability of the MB-based colorimetric immunoassay to the detection of TTX of razor clams, oysters and mussels was evaluated.



Figure 1. Schematic representation of the colorimetric MB-based colorimetric immunoassay for the detection of TTX. 


\section{MATERIAL AND METHODS}

\subsection{Reagents and solutions}

TTX standard was purchased from Abcam plc (Cambridge, UK) and the standard solution was prepared at $1 \mathrm{mg} / \mathrm{mL}$ in $1 \% \mathrm{v} / \mathrm{v}$ acetic acid. The anti-TTX monoclonal antibody TX-7F (mAb) was produced as described in Kawatsu et al. (1997). PureCube maleimide-activated MagBeads (MBs) were obtained from Cube Biotech (Monheim, Germany). Cysteamine hydrochloride, formaldehyde solution, potassium phosphate dibasic, potassium phosphate monobasic, Tween $^{\oplus}-20$, ethylenediaminetetraacetic acid (EDTA), bovine serum albumin (BSA), anti-mouse IgG (whole molecule)-horseradish peroxidase antibody (IgG-HRP) (IgG antibody produced in rabbit) and 3,3',5,5'-tetramethylbenzidine (TMB) liquid substrate were supplied by SigmaAldrich (Tres Cantos, Spain). Glacial acetic acid was obtained from Chem-lab (Zedelgem, Belgium). Ultrapure Milli-Q water $(18.2 \mathrm{M} \Omega / \mathrm{cm})$ was used to prepare the solutions (Millipore Ibérica Ltd., Madrid, Spain).

\subsection{Equipment}

TTXs extraction was performed using a water bath (model $6000138600 \mathrm{~W}$ ) from JP Selecta S. A. (Barcelona, Spain), an Alegra X-15R centrifuge from Beckman Coulter (Barcelona, Spain) and a DVX-2500 multi-tube vortex mixer from VWR International Eurolab S. L. (Barcelona, Spain). Magnetic separation was performed on a MagneSphere Technology Magnetic Separation Stand (for twelve 0.5-mL tubes) and a PolyATract System 1000 Magnetic Separation Stand (for one 15$\mathrm{mL}$ or 50-mL tube) from Promega Corporation (Madison, WI, USA). Colorimetric measurements were performed with a Microplate Reader KC4 from BIO-TEK Instruments, Inc. (Winooski, VT, USA). Gen5 software was used to collect and evaluate data. 


\subsection{Shellfish samples}

For the study of shellfish matrix effects, analysis of TTX-spiked shellfish extracts, and evaluation of repeatability/reproducibility of the system, Pacific oyster (Crassostrea gigas) ( $n=6)$, razor clam (Solen marginatus) ( $n=6)$ and mussel (Mytilus galloprovincialis) $(n=6)$ samples from the Ebro Delta (Alfacs Bay, NW Mediterranean Sea) were used. These shellfish samples were determined as TTXs negative by LC-MS/MS analysis. For the analysis of naturally-contaminated shellfish, Pacific oyster (Crassostrea gigas) ( $n=3$ ) and mussel (Mytilus edulis) $(n=3)$ samples were obtained from production sites in Oosterschelde (the Netherlands).

\subsection{TTXs extraction}

Extracts were obtained using the EURLMB protocol developed for the interlaboratory validation of HILIC-LC-MS/MS for TTX in mussels (EURLMB, 2017), with slight modifications (Turner et al., 2017). Briefly, $1 \mathrm{~g} \pm 0.1 \mathrm{~g}$ of shucked shellfish homogenate was weighed into a $15-\mathrm{mL}$ tube and $1 \mathrm{~mL}$ of $1 \% \mathrm{v} / \mathrm{v}$ acetic acid was added. After shaking the tube at $2500 \mathrm{rpm}$ for $5 \mathrm{~min}$ on a multitube vortex mixer, the sample was placed in a boiling water bath set at $100{ }^{\circ} \mathrm{C}$ for $10 \mathrm{~min}$. The tube was cooled and shaken again at $2500 \mathrm{rpm}$ for $5 \mathrm{~min}$. Finally, the sample was centrifuged at $4500 \mathrm{rpm}$ for $10 \mathrm{~min}$, and the supernatant was passed through a $0.2 \mu \mathrm{m}$ nylon filter and kept at $-20^{\circ} \mathrm{C}$ until analysis. The resulting extracts contained shellfish matrix at a concentration of 1000 mg equiv./mL.

\subsection{MB-based colorimetric immunoassay}

The MB-based colorimetric immunoassay protocol was similar to that described in our previous work on the electrochemical biosensor (Leonardo et al., 2019) but avoided the blocking step with BSA. Briefly: (1) $10 \mu \mathrm{L}$ of maleimide-activated MBs were transferred to a 1-mL tube and rinsed three times with $1 \mathrm{~mL}$ of washing buffer (0.1 M PBS, $0.05 \% v / v$ Tween $^{\oplus}-20, \mathrm{pH} 7.2$ ) under vigorous mixing; for the washing steps, the tube was placed on the magnetic separation stand and the washing solution was removed; (2) $1 \mathrm{~mL}$ of $1 \mathrm{mM}$ cysteamine in binding buffer $(0.1 \mathrm{M}$ 
PBS, 10 mM EDTA, pH 7.2) was added and incubated for $2 \mathrm{~h}$ at room temperature; (3) after three washing steps, $1 \mathrm{~mL}$ of TTX solution $(25 \mu \mathrm{g} / \mathrm{mL}$ ) in binding buffer containing $10 \% \mathrm{v} / \mathrm{v}$ formaldehyde was added and incubated overnight at $4{ }^{\circ} \mathrm{C}$; (4) three washing steps were performed and the TTX-coated MBs were resuspended in $1 \mathrm{~mL}$ of binding buffer. When amounts of MB varied, volumes were adjusted proportionally.

Once the MB-TTX conjugate had been prepared, (5) $200 \mu \mathrm{L}$ of the conjugate was transferred to a $0.5-\mathrm{mL}$ tube, the tube was placed on the magnetic separation stand, the supernatant was removed and $100 \mu \mathrm{L}$ of the TTX standard solution or shellfish extract and $100 \mu \mathrm{L}$ of anti-TTX mAb at $1 / 2000$ dilution in $1 \% \mathrm{w} / \mathrm{v}$ BSA-binding buffer were added and incubated for $30 \mathrm{~min}$ at room temperature; (6) after three washing steps, $200 \mu \mathrm{L}$ of $1 / 1000$ IgG-HRP dilution in $1 \% w / v$ BSAbinding buffer was incubated for $30 \mathrm{~min}$ at room temperature; (7) three washing steps were performed and the immunocomplex was resuspended in $200 \mu \mathrm{L}$ of binding buffer; (8) $50 \mu \mathrm{L}$ of immunocomplex was transferred to a new $0.5-\mathrm{mL}$ tube and after supernatant removal, $125 \mu \mathrm{L}$ of TMB liquid substrate was added and incubated for $10 \mathrm{~min}$; (9) the tube was placed on the magnetic separation stand and $100 \mu \mathrm{L}$ of TMB liquid substrate was collected for colorimetric measurement at $620 \mathrm{~nm}$ in a microtiter plate. All incubation steps were performed under agitation. Measurements were performed in triplicate.

\section{RESULTS}

\subsection{TTX calibration curve}

The use of MBs as immobilisation supports in immunoassays has advantages such as improved assay kinetics, more efficient washing steps and lower matrix effects (Pividori and Alegret, 2010; Pinacho et al., 2014). In this work, the blocking step with BSA, performed when developing the electrochemical biosensor (Leonardo et al., 2019), was avoided to shorten the assay turnaround. Since BSA was present during both the competition and incubation of the secondary antibody, non-specific adsorptions were not observed. The $T T X$ calibration curve, where mAb binding 
percentages were calculated with respect to the response obtained without TTX, was background-corrected with respect to controls with no anti-TTX mAb and fitted to a sigmoidal logistic four-parameter equation (Fig. 2). The strategy provided a limit of detection (LOD) for TTX, defined as the $20 \%$ inhibition coefficient $\left(I C_{20}\right)$, of $0.5 \mathrm{ng} / \mathrm{mL}$ and a working range $\left(\mathrm{IC}_{20}-\mathrm{IC}_{80}\right)$ of $0.5-9.1 \mathrm{ng} / \mathrm{mL}$. Surprisingly, this LOD was lower than that obtained with the electrochemical biosensor $(1.2 \mathrm{ng} / \mathrm{mL})$ and one possible explanation might be the use of a new anti-TTX mAb batch in this work.

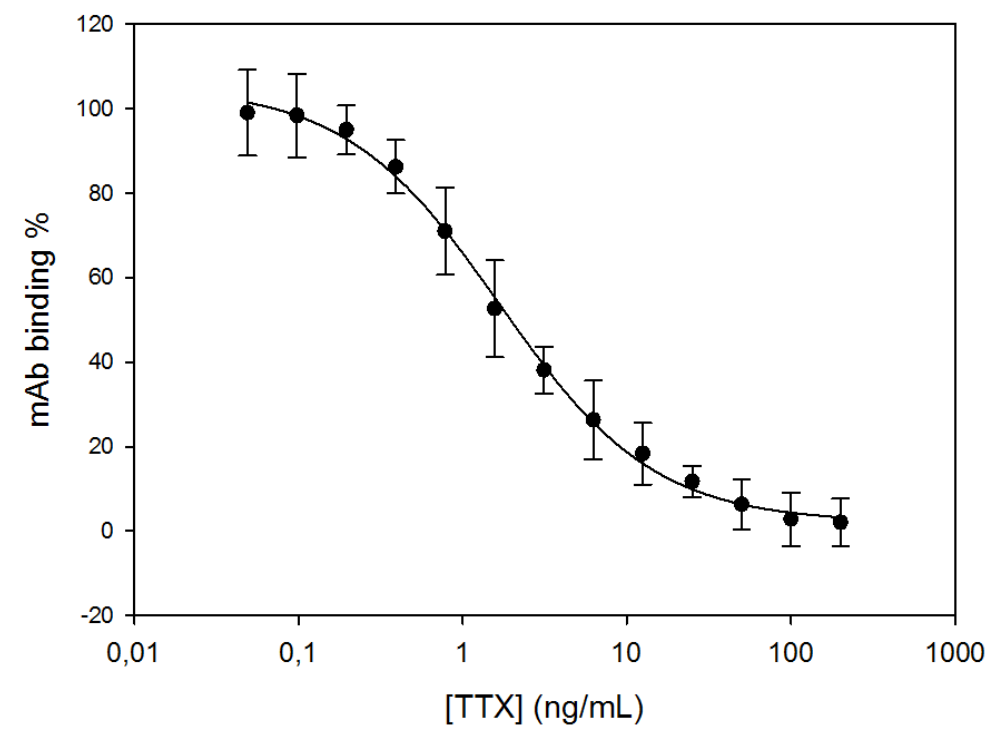

Figure 2. TTX calibration curve obtained by the MB-based colorimetric immunoassay. mAb binding is expressed as percentage of the control (no TTX). Error bars show SD values $(n=3)$.

\subsection{MB-TTX conjugate stability}

In order to shorten the assay even more, a MB-TTX conjugate pool was prepared, stored at $4{ }^{\circ} \mathrm{C}$, and the stability was evaluated by measuring the mAb binding percentage (in the absence of TTX) on different days compared with day 0 . As it can be observed in Fig. 3, values were always around $100 \%$ (interval range of $94-107 \%$ ), indicating excellent storage stability at least up to 45 days. Consequently, provided that MB-TTX conjugate is ready to use, analysis of samples can be performed in less than 1.5 hours. Moreover, the preparation of a single MB-TTX pool reduces the variability between assay runs, making the system more reproducible. 


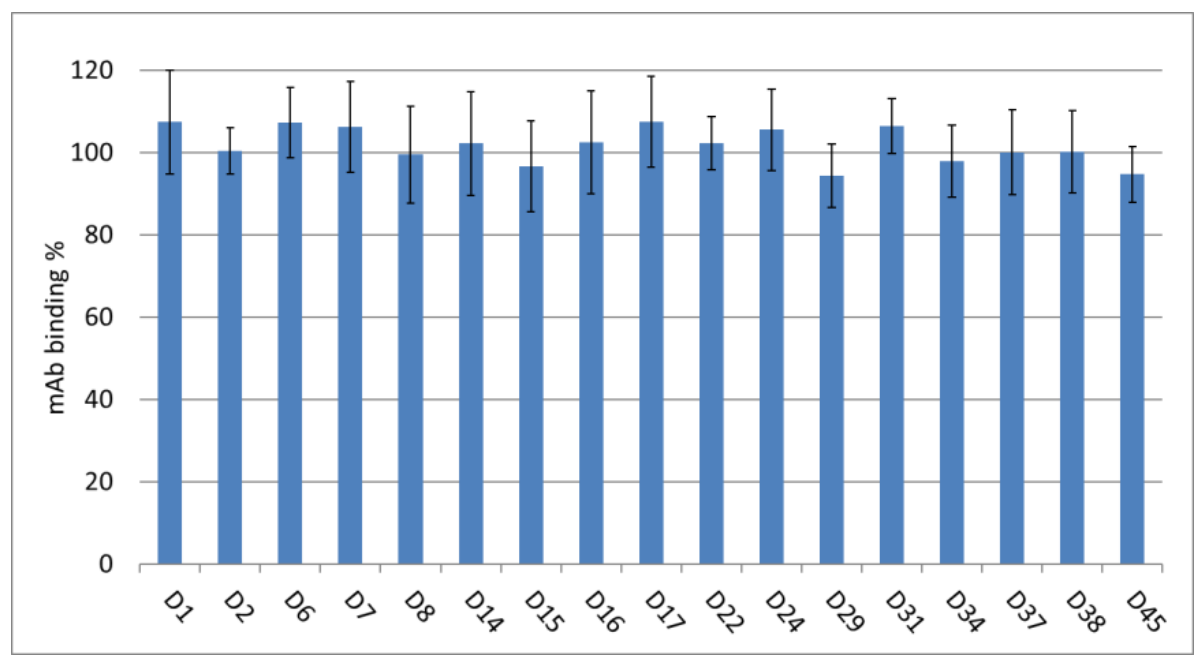

Figure 3. Stability of the MB-TTX conjugate after 45 days at $4{ }^{\circ} \mathrm{C}$. $\mathrm{mAb}$ binding is expressed as percentage of the control (no TTX). Error bars show SD values $(n=3)$.

\subsection{Shellfish matrix effects}

When analysing natural samples with immunoassays, the presence of compounds co-extracted with the analyte of interest may hinder the affinity interaction between the antibody and the antigen. Thus, the effect of the matrix should be evaluated carefully to avoid false positive or false negative results. Since our strategy is based on a competitive immunoassay, when the matrix is present but there is no toxin, mAb binding values of $100 \%( \pm 20 \%)$ indicate that the matrix is not interfering with the response. If mAb binding is inhibited, i.e. if the percentage is lower than $80 \%$, the matrix is causing a false positive result.

TTX-free oyster, razor clam and mussel extracts were analysed at different matrix concentrations (starting at $1000 \mathrm{mg}$ equiv./mL and at serial dilutions). For oysters, matrix effects were observed in 3 out of 6 samples when working at $1000 \mathrm{mg}$ equiv./mL (63-77\% mAb binding), but no matrix effects were observed when using $500 \mathrm{mg}$ equiv./mL or lower matrix concentrations. Matrix effects were observed in all razor clams samples when working at 1000 mg equiv./mL (57-75\% mAb binding), but no matrix effects were observed at $500 \mathrm{mg}$ equiv./mL or lower matrix concentrations. Regarding mussels, the highest matrix concentration that did 
not interfere with the immunoassay was $150 \mathrm{mg} / \mathrm{mL}$; matrix effects were observed from $200 \mathrm{mg}$ equiv./mL (60-73\% mAb biding) and higher in all samples tested.

Since the higher the shellfish matrix concentration the system can handle, the lower the TTX concentration that can be detected, matrix concentrations of $500 \mathrm{mg}$ equiv./mL for oysters and razor clams and $150 \mathrm{mg}$ equiv./mL for mussels were selected for subsequent experiments. Taking into account the LOD from the calibration curve $(0.5 \mathrm{ng} / \mathrm{mL})$ and the shellfish matrix concentrations allowed, effective LODs (eLODs) were calculated to be $1 \mu \mathrm{g} / \mathrm{kg}$ for oysters and razor clams and $3.3 \mu \mathrm{g} / \mathrm{kg}$ for mussels, well below the value proposed by EFSA ( $44 \mu \mathrm{g} / \mathrm{kg}$ ). These eLODs are also lower than the ones found with our previous immunoassay using microtiter plates (20-50 $\mu \mathrm{g} / \mathrm{kg}$ for oysters and $30 \mu \mathrm{g} / \mathrm{kg}$ for mussels) (Reverté et al., 2018). Working ranges upper limits were calculated to be $18.2 \mu \mathrm{g} / \mathrm{kg}$ for oysters and razor clams and $60.7 \mu \mathrm{g} / \mathrm{kg}$ for mussels.

\subsection{Analysis of TTX-spiked shellfish extracts}

Shellfish extracts ( $n=6$ for each species) were spiked at $20,10,5$ and $2.5 \mu g$ of TTX/kg equiv. of shellfish and analysed at $500 \mathrm{mg}$ equiv./mL for oysters and razor clams and at $150 \mathrm{mg}$ equiv. $/ \mathrm{mL}$ for mussels. TTX contents were determined using the proposed MB-based colorimetric immunoassay (Fig. 4). As it can be observed, TTX was detected in oysters and razor clams at all spiking levels. However, when analysing mussels, the lowest TTX concentration $(2.5 \mu \mathrm{g} / \mathrm{kg})$ was not detected. This is not surprising, since the eLOD was calculated to be $3.3 \mu \mathrm{g} / \mathrm{kg}$ for this shellfish species. From a quantitative point of view, the TTX concentrations determined were appropriate or slightly overestimated the spiked levels. Taking into account that the MB-based colorimetric immunoassay developed in this work aims to detect the presence of TTX in shellfish, this overestimation of the toxin content is not a drawback. In fact, if applied in a hypothetical official monitoring programme, the immunoassay would able to avoid false negative samples 
and identify the positive ones, which should be subsequently analysed by LC-MS/MS to be confirmed.
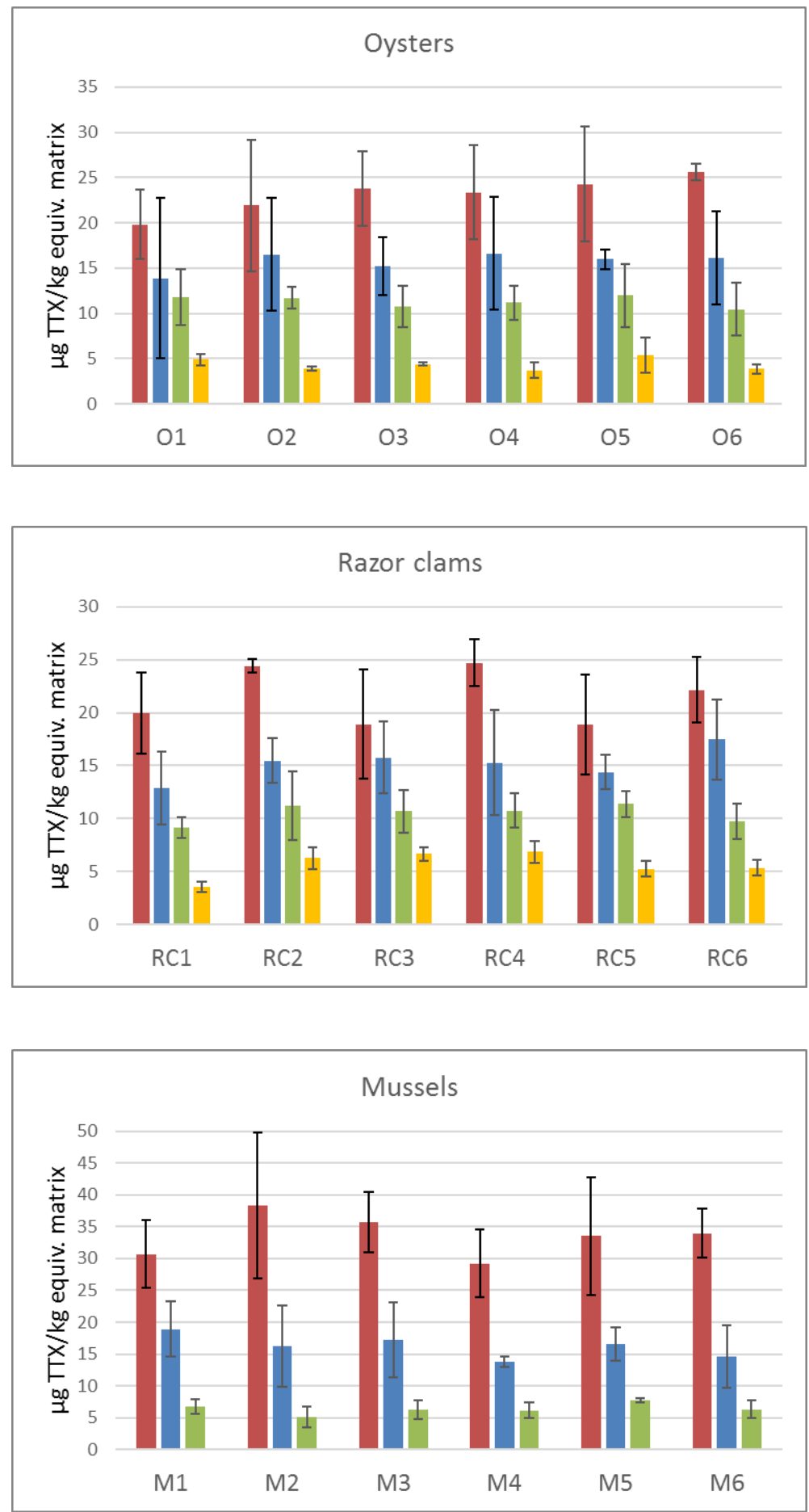

Figure 4. TTX concentrations ( $\mu \mathrm{g}$ of TTX/kg equiv. of shellfish) determined in TTX-spiked oysters ( $n=6)$, TTX-spiked razor clams $(n=6)$ and TTX-spiked mussels $(n=6)$. TTX-spiking levels were $20,10,5$ and $2.5 \mu \mathrm{g}$ of TTX/kg equiv. of shellfish (the mussels subfigure does not include the $2.5 \mu \mathrm{g}$ of TTX/kg equiv. level, as TTX was not detected). Error bars show SD values $(n=3)$. 
Repeatability (intra-day precision) was appropriate according to Horwitz equation, with relative standard deviation (RSD) values of $16.8,19.9$ and $19.9 \%$ for oysters, razor clams and mussels, respectively, at $10 \mu \mathrm{g}$ of $\mathrm{TTX} / \mathrm{kg}$ equiv. of shellfish. Reproducibility (inter-day precision) was also appropriate, with RSD values of $25.4,25.5$ and $19.5 \%$ for oysters, razor clams and mussels, respectively, also at $10 \mu \mathrm{g}$ of $\mathrm{TTX} / \mathrm{kg}$ equiv. of shellfish.

\subsection{Detection of TTX contents in naturally-contaminated samples}

The MB-based colorimetric immunoassay was applied to the analysis of three oyster and three mussel samples from Oosterschelde in the Netherlands. The presence of TTX was detected in all samples (Table 1). From a quantitative point of view, TTX concentrations ranged from less than $44 \mu \mathrm{g} / \mathrm{kg}$ up to two-fold higher. These results were compared with those obtained by LC-MS/MS analysis (Reverté et al., 2018). However, some discrepancies were observed. Several reasons could explain them: overestimation by the MB-based colorimetric immunoassay, overestimation by the LC-MS/MS analysis, detection of other TTX analogues by the immunoassay (LC-MS/MS only detected the parent TTX) or even the fact that samples were not extracted at the same moment and with the same extraction protocol. At this point, it is important to note that more samples (not available) would be necessary for a full validation. Despite these discrepancies, the results demonstrated that the MB-based colorimetric immunoassay can be used to detect the presence of TTX in shellfish samples at concentrations even lower than $44 \mu \mathrm{g} / \mathrm{kg}$, the current guidance threshold proposed by EFSA to safeguard human health.

Table 1. TTX concentrations ( $\mu \mathrm{g}$ of TTX/kg equiv. of shellfish) determined in 3 oyster and 3 mussel samples from the sanitary monitoring program of The Netherlands by the MB-based colorimetric immunoassay and comparison with LC-MS/MS analysis.

\begin{tabular}{|l|c|c|c|c|c|c|}
\hline & $\mathbf{0 1}$ & $\mathbf{0 2}$ & $\mathbf{0 3}$ & $\mathbf{M 1}$ & $\mathbf{M 2}$ & $\mathbf{M 3}$ \\
\hline MB-based immunoassay & $33 \pm 8$ & $47 \pm 8$ & $20 \pm 4$ & $49 \pm 4$ & $19 \pm 5$ & $90 \pm 6$ \\
\hline LC-MS/MS & 113 & 51 & 79 & 93 & 172 & 41 \\
\hline
\end{tabular}




\section{CONCLUSIONS}

A colorimetric MB-based colorimetric immunoassay for the detection of TTXs was applied to the analysis of shellfish (oysters, razor clams and mussels). The use of MBs as a TTX immobilisation support decreased the shellfish matrix effects observed in our previous works, where TTX was immobilised on microtiter plates. The analysis of spiked samples with the MB-based colorimetric immunoassay resulted in the detection of TTX contents at levels as low as $2.5 \mu \mathrm{g}$ of TTX/kg in oysters and razor clams, and $5 \mu \mathrm{g}$ of TTX/kg in mussels (eLODs being 1 and $3.3 \mu \mathrm{g}$ of TTX/kg, respectively). Because of the storage stability of the MB-TTX conjugate, the analysis can be performed in less than 1.5 hours. This is a very important advantage compared to conventional analysis techniques. In a hypothetical official monitoring programme, the MB-based colorimetric immunoassay would allow rapid identification of TTX-containing shellfish samples, at levels well below the EFSA guidance threshold of $44 \mu \mathrm{g} / \mathrm{kg}$. Subsequent analysis of positive samples by LCMS/MS could be used for confirmation. In summary, the colorimetric MB-based colorimetric immunoassay has been proved to be useful as a rapid and simple TTX detection method to safeguard shellfish safety and protect human health. This tool could be applied to control shellfish harvesting areas and manage stocks, and also in environmental studies regarding the presence of TTXs in other organisms or its distribution in different geographical areas.

\section{CONFLICTS OF INTEREST}

There are no conflicts to declare.

\section{ACKNOWLEDGEMENTS}

This research has received funding from the European Union's Horizon 2020 research and innovation programme under Grant Agreement no. 773400 (SEAFOOD ${ }^{\text {TOMORROW }}$ ). This output reflects the views only of the authors, and the European Union cannot be held responsible for any use which may be made of the information contained therein. The authors also acknowledge support from CERCA Programme/Generalitat de Catalunya. 


\section{Graphical abstract}

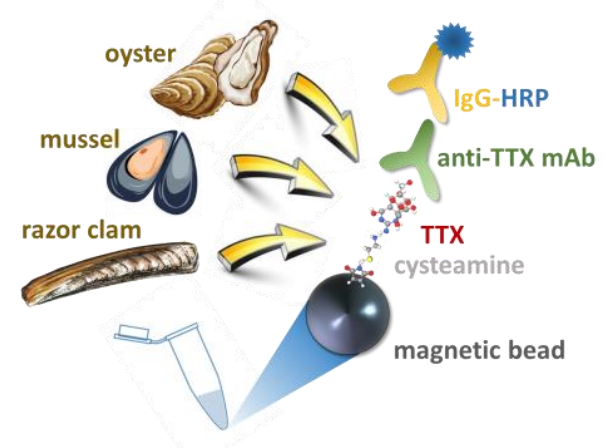

\section{REFERENCES}

Bane, V., Lehane, M., Dikshit, M., O'Riordan, A., Furey, A., 2014. Tetrodotoxin: Chemistry, Toxicity, Source, Distribution and Detection. Toxins. 6, 693-755.

https://doi.org/10.3390/toxins6020693

Dell'Aversano, C., Tartaglione, L., Polito, G., Dean, K., Giacobbe, M., Casabianca, S., Capellacci, S., Penna, A., Turner, A.D., 2019. First Detection of Tetrodotoxin and High Levels of Paralytic Shellfish Poisoning Toxins in Shellfish from Sicily (Italy) by Three Different Analytical Methods. Chemosphere 215, 881-892.

https://doi.org/10.1016/J.CHEMOSPHERE.2018.10.081

EFSA (European Food Safety Authority), 2017. Risks for Public Health Related to the Presence of Tetrodotoxin (TTX) and TTX Analogues in Marine Bivalves and Gastropods. EFSA J. 15, 4752. https://doi.org/10.2903/j.efsa.2017.4752

EURLMB (European Union Reference Laboratory for Marine Biotoxins), 2017. Determination of Tetrodotoxin by HILIC-MS/MS.

http://www.aecosan.msssi.gob.es/en/CRLMB/docs/docs/metodos_analiticos_de_desarr ollo/HILIC-LCMSMS_SOP_for_TTX_in_mussels.pdf (accessed 30 September 2019).

Gerssen, A., Bovee, T., Klijnstra, M., Poelman, M., Portier, L., Hoogenboom, R., 2018. First Report on the Occurrence of Tetrodotoxins in Bivalve Mollusks in The Netherlands. 
Toxins. 10, 450. https://doi.org/10.3390/toxins10110450

Kawatsu, K., Hamano, Y., Yoda, T., Terano, Y., Shibata, T., 1997. Rapid and Highly Sensitive Enzyme Immunoassay for Quantitative Determination of Tetrodotoxin. Japanese J. Med. Sci. Biol. 50, 133-150. https://doi.org/10.7883/yoken1952.50.133

Leão, J., Lozano-Leon, A., Giráldez, J., Vilariño, Ó., Gago-Martínez, A., 2018. Preliminary Results on the Evaluation of the Occurrence of Tetrodotoxin Associated to Marine Vibrio spp. in Bivalves from the Galician Rias (Northwest of Spain). Mar. Drugs 16, 81. https://doi.org/10.3390/md16030081

Leonardo, S., Kiparissis, S., Rambla-Alegre, M., Almarza, S., Roque, A., Andree, K.B., Christidis, A., Flores, C., Caixach, J., Campbell, K., Elliott, C.T., Aligizaki, K., Diogène, J., Campàs, M., 2019. Detection of Tetrodotoxins in Juvenile Pufferfish Lagocephalus sceleratus (Gmelin, 1789) from the North Aegean Sea (Greece) by an Electrochemical Magnetic Bead-Based Immunosensing tool. Food Chem. 290, 255-262. https://doi.org/10.1016/j.foodchem.2019.03.148

Mahmud, Y., Yamamori, K., Noguchi, T., 1999. Occurrence of TTX in a Brackish Water Puffer "Midorifugu", Tetraodon nigroviridis, collected from Thailand. Food Hyg. Saf. Sci. 40, 363-367. https://doi.org/10.3358/shokueishi.40.5_363

Magarlamov, T. Y., Melnikova, D. I., Chernyshev, A. V., 2017. Tetrodotoxin-Producing Bacteria: Detection, Distribution and Migration of the Toxin in Aquatic Systems. Toxins 9, 166. https://doi.org/10.3390/toxins9050166

Noguchi, T., Arakawa, O., Takatani, T., 2006. TTX Accumulation in Pufferfish. Comp. Biochem. Physiol. Part D Genomics Proteomics 1, 145-152.

https://doi.org/10.1016/J.CBD.2005.10.006

Pinacho, D., Sánchez-Baeza, F., Pividori, M.-I., Marco, M.-P., 2014. Electrochemical Detection of Fluoroquinolone Antibiotics in Milk Using a Magneto Immunosensor. Sensors 14, 15965- 
15980. https://doi.org/10.3390/s140915965

Pividori, M.I., Alegret, S., 2010. Micro and Nanoparticles in Biosensing Systems for Food Safety and Environmental Monitoring. An Example of Converging Technologies. Microchim. Acta 170, 227-242. https://doi.org/10.1007/s00604-010-0347-8

Reverté, L., Rambla-Alegre, M., Leonardo, S., Bellés, C., Campbell, K., T.Elliott, C., Gerssen, A., D.Klijnstra, M., Diogène, J., Campàs, M., 2018. Development and Validation of a Maleimide-Based Enzyme-Linked Immunosorbent Assay for the Detection of Tetrodotoxin in Oysters and Mussels. Talanta 176, 659-666.

https://doi.org/10.1016/J.TALANTA.2017.08.058

Rodriguez, P., Alfonso, A., Vale, C., Alfonso, C., Vale, P., Tellez, A., Botana, L.M., 2008. First Toxicity Report of Tetrodotoxin and 5,6,11-TrideoxyTTX in the Trumpet Shell Charonia lampas lampas in Europe. Anal. Chem. 80, 5622-5629.

https://doi.org/10.1021/ac800769e

Turner, A., Powell, A., Schofield, A., Lees, D., Baker-Austin, C., 2015. Detection of the Pufferfish Toxin Tetrodotoxin in European Bivalves, England, 2013 to 2014. Eurosurveillance 20, 21009. https://doi.org/10.2807/1560-7917.ES2015.20.2.21009

Turner, A.D., Boundy, M.J., Rapkova, M.D., 2017. Development and Single-Laboratory Validation of a Liquid Chromatography Tandem Mass Spectrometry Method for Quantitation of Tetrodotoxin in Mussels and Oysters. J. AOAC Int. 100, 1469-1482. https://doi.org/10.5740/jaoacint.17-0017

Vlamis, A., Katikou, P., Rodriguez, I., Rey, V., Alfonso, A., Papazachariou, A., Zacharaki, T., Botana, A., Botana, L., 2015. First Detection of Tetrodotoxin in Greek Shellfish by UPLCMS/MS Potentially Linked to the Presence of the Dinoflagellate Prorocentrum minimum. Toxins (Basel). 7, 1779-1807. https://doi.org/10.3390/toxins7051779 